DOI 10.14746/ssp.2017.3.3

Arkadiusz PTAK

Polska Akademia Nauk

\title{
Determinanty rywalizacji wyborczej w lokalnych elekcjach samorządowych
}

\begin{abstract}
Summary: Celem artykułu jest przedstawienie i wyjaśnienie czynników, które wpłynęły na strukturę rywalizacji wyborczej oraz wynik wyborów, a w konsekwencji lokalne sceny polityczne po wyborach samorządowych w 2014 roku. Wśród głównych analizowanych determinant są: 1) zmiany samorządowego prawa wyborczego; 2) sytuacja społeczno-polityczna w Polsce u progu wyborów samorządowych oraz 3) charakter lokalnych scen politycznych. Prowadzone badania uwidoczniły zjawisko wycofywania się partii politycznych z bezpośredniej rywalizacji wyborczej na szczeblu lokalnym. Przykłady badanych gmin wskazują, że wielu lokalnych działaczy samorządowych posiadło doskonałe umiejętności ,politycznej adaptacji” do zmieniających się nastrojów społecznych. Natomiast konsekwencją zmian w prawie wyborczym, a zwłaszcza wprowadzenia formuły większościowej w wyborach do rad gmin, są m.in. 1) dodatkowe wzmocnienie pozycji burmistrza i jego bezpośredniego zaplecza politycznego w lokalnym systemie władzy; 2) dysproporcjonalność wyników wyborów; 3) niewielkie zainteresowanie bezpośrednim udziałem w rywalizacji wyborczej osób bez instytucjonalnego zaplecza politycznego oraz 4) koncentrowanie się radnych w swojej działalności na problemach własnego okręgu wyborczego. Czynnikiem w największym stopniu determinującym lokalne elekcje samorządowe, a w konsekwencji charakter i kształt lokalnego systemu władzy, jest osoba burmistrza (prezydenta miasta).
\end{abstract}

Słowa kluczowe: wybory samorządowe, gmina, formuła wyborcza, JOW, burmistrz

\section{Wprowadzenie}

Specyfika podmiotów uczestniczących w rywalizacji wyborczej do lokalnych władz samorządowych w Polsce utrudnia określenie nie tylko struktury rywalizacji wyborczej, ale przede wszystkim zwycięzców tychże elekcji. Takiej możliwości już od 1990 roku nie daje statystyka prowadzona przez Państwową Komisję Wyborczą (wcześniej Generalnego Komisarza Wyborczego), która uwzględnia podział podmiotów uczestniczących w wyborach lokalnych zastosowany przez ustawodaw- 
cę. Formalnie więc podmiotami tymi są komitety wyborcze utworzone przez: 1) partie polityczne i ich koalicje; 2) organizacje oraz 3) wyborców (Kodeks wyborczy, 2011). Jednak z punktu widzenia wielu badań i analiz z zakresu nauk politycznych taki podział podmiotów jest nieprecyzyjny. Tworzy się więc alternatywne typologie podmiotów lokalnej polityki (Kurczewski, 2008, s. 218; Kurczewski, 2007, s. 574; Alberski i in., 2001, s. 48-49; Ptak, 2014, s. 104-120).

Tym, co od początku wyróżnia polski samorząd lokalny, mając jednocześnie bezpośredni związek z rywalizacją wyborczą oraz lokalną polityką, jest antypartyjność, wokół której stworzono swoistą ideologię. Być może źródeł tego zjawiska należy szukać wśród samych twórców reformy samorządowej w 1990 roku. Owa niechęć do partii politycznych mogła wynikać z faktu, że reprezentowali oni przede wszystkim nauki prawne i ekonomiczne (a nie socjologię czy politologię), a co więcej, prowadząc swoje badania nad samorządem jeszcze w okresie Polski Ludowej, za „przeciwnika" mieli właśnie partię (Polską Zjednoczoną Partię Robotnicza), dla której samorząd był instytucją obcą ustrojowo, zaś władza lokalna opierała się na systemie rad narodowych. Antypartyjna ideologia została przyjęta i zaczęła dominować w środowisku naukowym głównie za sprawą wpływów, jakie miało to środowisko w czołowych czasopismach skierowanych zarówno do przedstawicieli nauki (,Samorzą Terytorialny”), jak i bezpośrednio do samorządowców („Wspólnota”). Cieszyła się ona również uznaniem wśród lokalnych działaczy samorządowych, podobnie jak wśród samych mieszkańców gmin. Także trudny i skomplikowany proces instytucjonalizacji partii politycznych w okresie transformacji systemowej nie zachęcał do bezpośredniego angażowania się samorządowców w działalność partyjną na szczeblu lokalnym.

W opozycji do partii politycznych tworzono lokalne ugrupowania polityczne, które miały jednak zróżnicowany charakter zarówno pod względem relacji z partiami politycznymi, jako głównymi aktorami życia politycznego w systemie demokratycznym, jak i pod względem celów swojej działalności, doświadczenia w lokalnej rywalizacji wyborczej czy też obszaru działania. Uwarunkowania te sprawiają, że bardzo trudno prowadzić badania w skali ogólnopolskiej.

Specyfika badań lokalnej polityki, wynikająca głównie z trudności $\mathrm{w}$ identyfikacji politycznej podmiotów uczestniczących w rywalizacji wyborczej, skłoniła autora do przeprowadzenia badań z wykorzystaniem metody porównawczych studiów przypadku. Została ona wzbogacona o metodę obserwacji bezpośredniej. Przedmiotem dociekań stało się 
sześć gmin zlokalizowanych w południowej części Wielkopolski. Pięć z nich to gminy miejsko-wiejskie (Jarocin, Kępno, Krotoszyn, Ostrzeszów, Pleszew), zamieszkiwane przez od ponad 23 do 45 tysięcy mieszkańców (połowa mieszkańców badanych gmin zamieszkiwała obszary wiejskie). Jedyną gminą miejską był ponad siedemdziesięciotysięczny Ostrów Wielkopolski. Wybór takiej metody badawczej pozwolił dość szczegółowo poznać specyfikę rywalizacji wyborczej, a nie analizować ją wyłącznie przez pryzmat statystyk Państwowej Komisji Wyborczej, które nie uwzględniają nie tylko specyfiki badanego terenu, ale również wielu czynników determinujących rywalizację wyborczą. Czynnikami determinującymi wybór gmin do badań to przede wszystkim fakt, że są to jednostki powyżej 20000 mieszkańców. Nastąpiła więc w nich zmiana formuły wyborczej z proporcjonalnej na większościową. Po wtóre, są to gminy miejsko-wiejskie (poza jedna). Można więc w prowadzonych analizach uwzględnić dość widoczny jeszcze w Polsce element podziału na miasto i wieś (np. jeśli chodzi o poparcie dla partii politycznych). Ponadto wszystkie gminy są również siedzibami władz powiatowych, stąd należy zakładać, że główne partie polityczne powinny mieć tam własne struktury i bezpośrednio uczestniczyć w rywalizacji wyborczej. Badane gminy już wcześniej (lata 2002-2010) były obszarem eksploracji (Ptak, 2011)․․ Oprócz danych Państwowej Komisji Wyborczej wykorzystano również lokalną prasę, materiały wyborcze poszczególnych ugrupowań oraz wywiady bezpośrednie z aktorami bądź obserwatorami lokalnej polityki.

Niniejszy tekst stawia więc sobie za cel przedstawienie i wyjaśnienie czynników, które wpłynęły nie tylko na strukturę rywalizacji wyborczej, ale również na sam wynik wyborów i lokalne sceny polityczne po wyborach samorządowych. Struktura rywalizacji wyborczej obejmuje głównie analizę podmiotów uczestniczących w wyborach ze szczególnym uwzględnieniem komitetów wyborczych partii politycznych, ugrupowań stanowiących zaplecze polityczne burmistrzów oraz komitetów stosujących kamuflaż polityczny. Za ostatnią grupę podmiotów przyjmuje się komitety utworzone przez lokalnych działaczy partii politycznych, którzy z uwagi na uwarunkowania lokalne, bądź ogólnopolskie odstąpili od startu w wyborach w ramach partyjnego komitetu wyborczego. Identyfikacji takich podmiotów służyła przede wszystkim analiza materiałów wyborczych, lektura lokalnej prasy, wywiady bezpośrednie oraz dane Państwo-

${ }^{1}$ W niniejszych badaniach nie uwzględniono jedynie Kalisza, bowiem w wyborach do rady gminy zachowano formułę proporcjonalną, co uniemożliwiło porównywanie go z pozostałymi jednostkami. 
wej Komisji Wyborczej z wcześniejszych elekcji. Wg podobnych podziałów przedstawiono wyniki wyborów samorządowych. Podstawowy materiał empiryczny do badań w tej części pochodził z Państwowej Komisji Wyborczej. Trzeci element poddany badaniu to lokalne sceny polityczne po wyborach samorządowych. Skoncentrowano się na układzie sił politycznych w radzie, zwłaszcza pozycji, jaką posiada w radzie zaplecze polityczne burmistrzów oraz relacji rada-burmistrz.

Do głównych analizowanych determinant należą: 1) zmiany samorządowego prawa wyborczego; 2) sytuacja społeczno-polityczna w Polsce u progu wyborów samorządowych w 2014 roku oraz 3) specyfika lokalnych scen politycznych.

Ramy teoretyczne badań nad wpływem prawa wyborczego na lokalną politykę wyznaczają prawa i hipotezy sformułowane przez francuskiego politologa Maurice`a Duvergera, według którego na kształt systemu partyjnego wpływa system wyborczy. Duverger wskazywał, że wprowadzenie systemu większościowego sprzyja powstawaniu systemu dwupartyjnego. Dzieje się tak dlatego, że słabsze partie uzyskują w parlamencie dużo mniej miejsc, niż zdobywają głosów. O liczbie uzyskanych mandatów nie decyduje liczba głosów w skali kraju, a uzyskanie przewagi, nawet minimalnej, w większej niż przeciwnicy liczbie okręgów wyborczych (,zwycięzca bierze wszystko”). Efekt ten został nazwany przez Duvergera efektem mechanicznym. Drugie zjawisko to efekt psychologiczny - potencjalni wyborcy mniejszych partii, w obawie przed utratą swoich głosów na skutek działania zasady mechanicznej, sami rezygnują z ich popierania na rzecz najsilniejszych (Duverger, 1954).

Impulsem do analiz lokalnych scen politycznych jest kryzys partii politycznych na tym szczeblu władzy i wzmacnianie się niezależnych wobec partii politycznych burmistrzów i radnych. I choć zjawisko to obserwuje się również w innych państwach Europy, to jednak Polska przywoływana jest jako przykład kraju, w którym proces ten występuje najczęściej (Swianiewicz, 2016, s. 30).

Przyjęto dwie hipotezy. Pierwsza zakłada, że rozszerzenie ordynacji większościowej o gminy powyżej 20000 mieszkańców nie tylko wzmocniło najsilniejsze ugrupowania lokalnej polityki, ale również nie zaktywizowało mieszkańców do rejestrowania własnych, wcześniej nieobecnych, komitetów wyborczych. Druga z hipotez zakłada, że specyfika lokalnych aren rywalizacji wyborczej (wynikająca m.in. z silnej pozycji ugrupowań pozapartyjnych stanowiących zaplecza polityczne burmistrzów) wraz z aktualnym poparciem społecznym wpływa na charakter udziału partii poli- 
tycznych w wyborach samorządowych w kierunku bądź to bezpośredniego udziału w rywalizacji, bądź też stosowania kamuflażu politycznego.

\section{Zmiany samorządowego prawa wyborczego}

Paradoksalnie częste zmiany samorządowego prawa wyborczego w Polsce dają dość unikalną możliwość prowadzenia badań porównawczych. W tym względzie badacze władzy lokalnej z Europy Zachodniej czy Stanów Zjednoczonych nie mają takich możliwości. Systemy wyborcze są tam bardziej stabilne i pozbawiają badaczy bogatego materiału empirycznego.

W ciągu ostatniego ćwierćwiecza w polskim samorządowym prawie wyborczym dokonywano zmian w zasadzie wszystkich najważniejszych jego elementów, do których należały m.in.: 1) formuła wyborcza; 2) wielkość okręgów wyborczych; 3) blokowanie list wyborczych; 4) zmniejszanie liczby wybieranych radnych; 5) zmiana sposobu wyboru organu wykonawczego gminy; 6) sposób podziału mandatów przy proporcjonalnej formule wyborczej; 7) zasady zgłaszania kandydatów i list kandydatów na radnych czy 8) zmiany godzin głosowania (Ptak, 2010, s. 143-152). Także ostatnie wybory samorządowe z 2014 roku nie tylko zostały przeprowadzone w oparciu o całkowicie nowy akt prawny (Kodeks wyborczy, 2011), przede wszystkim wprowadzono także dość istotne korekty do dotychczas obowiązujących rozwiązań. Jednak zainteresowanie ostatnią elekcją skupiło się przede wszystkim na problemach Państwowej Komisji Wyborczej z podaniem ostatecznych wyników wyborów do sejmików wojewódzkich. Formułowane były zarzuty o złej organizacji pracy PKW, niewłaściwej konstrukcji karty do głosowania, a nawet oskarżenia o sfałszowanie wyborów, co nie znalazło potwierdzenia w późniejszych analizach (Gendźwiłł i in., 2016). Na marginesie pozostały analizy poświęcone zmianie formuły wyborczej w wyborach do rady gmin (poza miastami na prawach powiatów).

Formuła wyborcza to, obok struktury głosu oraz wielkości okręgu, najważniejszy element systemu wyborczego, który w największym stopniu determinuje wynik wyborów. Do podstawowych formuł wyborczych należa: 1) proporcjonalna; 2) większościowa oraz 3) pośrednia (mieszana) (zob.: Haman, 2003, s. 74-75). Wszystkie trzy formuły są lub były wykorzystywane w polskich elekcjach na różnych szczeblach władzy publicznej po 1989 roku. 
Analizowane w niniejszym tekście zmiany dotyczą zmiany formuły pośredniej (w gminach do 20000 mieszkańców) oraz proporcjonalnej (w gminach powyżej 20000 mieszkańców) w wyborach do rad gmin, na formułę większościową. Wielomandatowe okręgi wyborcze charakterystyczne dla dwóch pierwszych systemów ${ }^{2}$ zastąpione zostały okręgami jednomandatowymi (tzw. JOW-ami), z których wybierany był tylko jeden kandydat. Kandydaci na liście wyborczej nie byli jednak umieszczani w kolejności alfabetycznej. Przyjęto rozwiązanie dające pierwsze miejsca osobom reprezentującym te komitety wyborcze, które zarejestrowały kandydatów w co najmniej połowie okręgów wyborczych w wyborach do wszystkich sejmików województw. Na siedem komitetów wyborczych spełniających ten warunek cztery były komitetami największych polskich partii politycznych mających wówczas swoją reprezentację w parlamencie. Listy kandydatów tych komitetów otrzymały te same numery na wszystkich szczeblach samorządu terytorialnego, także w wyborach do rad gmin. Dopiero kolejne numery na liście wyborczej przypisano lokalnym komitetom wyborczym. Stąd też, jeżeli w wyborach do danej rady uczestniczyły wskazane wyżej komitety wyborcze partii politycznych, ich kandydaci byli umieszczeni w pierwszej kolejności na liście wyborczej. Dopiero kolejne miejsca przypadły kandydatom z list lokalnych komitetów wyborczych.

Istotnym elementem jednomandatowych okręgów wyborczych jest metoda głosowania. W elekcji z 2014 roku przyjęto metodę większości względnej. W wyborach do rady gminy wygrywał kandydat $\mathrm{z}$ najwyższym odsetkiem głosów w okręgu.

Trudno wskazać inny element systemu wyborczego, który budziłby tak ożywioną dyskusję, jak formuła wyborcza. W dyskursie publicznym zdecydowanie dominują zwolennicy Jednomandatowych Okręgów Wyborczych z metodą większościową, którzy są nawet zrzeszeni w Stowarzyszeniu na rzecz Zmiany Systemu Wyborczego - Jednomandatowe Okręgi Wyborcze. Celem stowarzyszenia jest ,[...] dążenie do wprowadzenia w Polsce większościowego systemu wyborczego z równą dla wszystkich swobodą kandydowania i podziałem na 460 jednomandatowych okręgów wyborczych w wyborach do Sejmu RP oraz wspieranie organizacyjne i rzeczowe osób fizycznych i jednostek organizacyjnych,

${ }^{2} \mathrm{~W}$ gminach do 20000 mieszkańców w okręgach wyborczych wybierano od 1 do 5 radnych. O wielkości okręgów wyborczych decydowały poszczególne rady gmin. De facto w części tych gmin kandydaci na radnych wyłaniani byli w jednomandatowych okręgach wyborczych (JOW). 
które podejmują takie działania" (www.jow.pl). Krytyka proporcjonalnego systemu wyborczego koncentruje się na tym, że system ten: 1) nadmiernie upartyjnia wybory; 2) skutkuje rozdrobnieniem partii w parlamencie; 3) mniejszym partiom daje często dużą władzę; 4) może powodować nadmierną lojalność posłów wobec kierownictwa partii (www.jow.pl). W literaturze wskazuje się jednak na pewne zagrożenia i konsekwencje związane z wdrożeniem JOW-ów. Marek M. Kamiński, badacz systemów wyborczych, a przede wszystkim zwolennik takiego systemu wyborczego, wskazuje na: 1) wyłonienie się systemu dwupartyjnego (choć dla zwolenników JOW-ów jest to jeden z głównych argumentów na rzecz tych zmian); 2) większą możliwość manipulowania granicami okręgów wyborczych; 3) zmniejszenie konkurencyjności wyborów oraz 4) zwiększoną motywację do marnotrawnego rozdawnictwa funduszy centralnych (Kamiński, 2016, s. 39 i nast.).

Jednomandatowe okręgi wyborcze, głównie za sprawą P. Kukiza, stały się również jednym z elementów debaty podczas ostatnich wyborów Prezydenta RP, a w konsekwencji ogólnokrajowego referendum (6.09.2015). Starający się o reelekcję B. Komorowski przed II turą wyborów, chcąc pozyskać wyborców Kukiza, zapowiedział przeprowadzenie referendum, proponując jako jedno z pytań „Czy jest Pan/i za wprowadzeniem jednomandatowych okręgów wyborczych w wyborach do Sejmu Rzeczypospolitej Polskiej?". Przy bardzo niskiej frekwencji (7,80\%) blisko $80 \%$ biorących udział w referendum opowiedziało się za takim rozwiązaniem.

Co prawda głównym postulatem zwolenników JOW-ów jest zmiana sposobu przeprowadzania wyborów do Sejmu RP, jednak dotyczy on również innych szczebli władzy publicznej, w tym jednostek samorządu terytorialnego.

\section{Sytuacja społeczna i polityczna w Polsce u progu wyborów samorządowych w 2014 roku}

W 2014 roku władzę w Polsce na szczeblu centralnym od siedmiu lat sprawowała koalicja Platformy Obywatelskiej RP oraz Polskiego Stronnictwa Ludowego. W wyborach, które odbyły się 9 października 2011 roku, pierwsza z partii zdobyła 39,18\% głosów i dysponowała 207 mandatami (45\% mandatów w Sejmie), druga zaś - PSL - 8,36\% głosów z 28 mandatami (6,08\%). Swoją reprezentację w Sejmie miały także: Prawo i Sprawiedliwość - 29,89\% głosów (157 mandatów), Ruch Palikota 
- 10,02\% głosów (40 mandatów) oraz Sojusz Lewicy Demokratycznej - 8,24\% głosów (27 mandatów). Jedno miejsce przypadło przedstawicielowi komitetu wyborczego Mniejszości Niemieckiej. Władza koalicji PO-PSL rozciaggała się jeszcze na szczebel regionalny, który z uwagi na kluczową rolę w dystrybucji środków z Unii Europejskiej stał się istotnym ogniwem władzy publicznej.

W połowie 2014 roku (25.05) odbyły się wybory do Parlamentu Europejskiego. Tradycyjnie przy niskiej frekwencji wyborczej $(23,8 \%)$ dwie główne partie: PO i PiS zdobyły porównywalną liczbę głosów. Na pierwszą z nich zagłosowało 32,13\% wyborców, zaś na drugą - 31,78\%. Partie zdobyły po 19 mandatów w PE, a różnica między partiami wyniosła zaledwie 24345 głosów. Jednak dwa komitety wyborcze, które w przyszłości de facto przyłączone zostaną do PiS, zdobyły pół miliona głosów (Solidarna Polska Z. Ziobry - ponad 280000 głosów, zaś Polska Razem J. Gowina - ponad 220000 głosów). Były to więc pierwsze symptomy zmieniającej się tendencji w poparciu społecznym dla dwóch głównych ugrupowań politycznych.

Innym źródłem obrazującym sytuację społeczno-polityczną tego okresu są comiesięczne raporty Centrum Badania Opinii Społecznej (CBOS). $\mathrm{Z}$ jednego z nich, przeprowadzonego w drugiej połowie sierpnia 2014 roku (CBOS 121/2014), wynika, że aż 62\% badanych twierdziło, że ogólna sytuacja w kraju zmierza w złym kierunku. Tylko jedna piąta (21\%) oceniła ją pozytywnie. Zadowolenie z ogólnej sytuacji w kraju dominowało jedynie wśród elektoratu PO (61\%), ale już wśród osób popierających PSL przeważało rozczarowanie (46\%). Szczególnie krytyczni wobec sytuacji w kraju byli rolnicy. Pogarszała się również opinia wyborców na temat sytuacji gospodarczej kraju, także przewidywanej. W innym badaniu CBOS-u pytano respondentów o zaufanie do polityków (CBOS 120/2014). Badania prowadzono już po ujawieniu nagrań polityków i przedstawicieli biznesu (tzw. „afera taśmowa”). Największym zaufaniem Polaków niezmiennie cieszył się prezydent B. Komorowski. Zaufanie do prezydenta deklarowało blisko trzy czwarte badanych (73\%). Kolejne miejsca w rankingu zaufania zajmowali R. Sikorski (40\% zaufania), E. Kopacz (35\%), L. Miller (33\%), D. Tusk i J. Kaczyński (po 32\%). Dla krajowej polityki istotne znaczenie miał również wybór D. Tuska na przewodniczącego Rady Europejskiej (30.08). Już w momencie jego wyboru ponad $44 \%$ badanych uważało, że odejście Tuska z krajowej polityki osłabi Platformę Obywatelską (CBOS 127/2014). Z drugiej jednak strony, po jego rezygnacji z funkcji premiera, poprawiły się notowania rządu. Przybyło 
zwolenników urzędującego gabinetu, wzrosło także zadowolenie z tego, że premierem jest Ewa Kopacz. Rząd miał więcej zwolenników niż przeciwników. Był to wynik nienotowany od kilku lat (od czasu „pierwszego” rządu D. Tuska) (CBOS 156/2014).

W ostatnim badaniu preferencji partyjnych przed wyborami samorządowymi i już po wyborze Tuska na przewodniczącego Rady Europejskiej poprawiły się notowania Platformy Obywatelskiej. W połowie września na PO chciało głosować 38\% potencjalnych wyborców i był to najlepszy wynik partii rządzącej od lutego 2012 roku, znacznie lepszy (wzrost o 12 punktów procentowych) od uzyskanego przez to ugrupowanie w sondażu przeprowadzonym w drugiej połowie sierpnia. Na Prawo i Sprawiedliwość wraz z Polską Razem Jarosława Gowina i Solidarną Polską Zbigniewa Ziobry chciało głosować 33\% badanych. Kolejne miejsca zajęły Polskie Stronnictwo Ludowe (7\%), Sojusz Lewicy Demokratycznej oraz Nowa Prawica Janusza Korwin-Mikkego (po 6\%) oraz Twój Ruch (2\%) (CBOS 126/2014).

Na podstawie badań CBOS-u, a zwłaszcza notowań samej Platformy Obywatelskiej, rządu Ewy Kopacz czy zaufania dla czołowych polityków rządzącej partii, można wskazać, że istniały przesłanki do bezpośredniego udziału Platformy Obywatelskiej w rywalizacji wyborczej na szczeblu lokalnym.

\section{Lokalne sceny polityczne w latach 2002-2010}

Lokalne sceny polityczne badanych gmin w okresie poprzedzającym elekcję samorządową z 2014 roku zdominowane były przez dwie grupy podmiotów (Ptak, 2011). Pierwsza to partie polityczne, których pozycja stawała coraz silniejsza. Na ich wynik wyborczy miały wpływ głównie popularność i wyniki osiagane przez partię w skali całego kraju oraz aktywność terenowych struktur partyjnych. O ile wybory z lat 2002 i 2006 kończyły się sukcesem lewicy, o tyle w 2010 roku sukces odniosła Platforma Obywatelska. Przez cały czas bardzo silne było Polskie Stronnictwo Ludowe. W rywalizacji wyborczej uczestniczyło również Prawo i Sprawiedliwość. Partie polityczne, poza pojedynczymi przypadkami, coraz rzadziej wystawiały listy partyjne pod nazwą lokalnego komitetu wyborczego, stosując kamuflaż polityczny, co w przeszłości było zjawiskiem powszechnym. W 2002 roku, a nawet jeszcze w roku 2006, zjawisko to było zauważalne w środowiskach prawicowych, a za lokalnymi 
komitetami „ukrywały się” najczęściej Platforma Obywatelska oraz Prawo i Sprawiedliwość. W 2010 roku podobne zjawisko uwidoczniło się w na lewicy. Umacnianie się partii politycznych w lokalnej polityce po wyborach 2010 roku zauważalne jest również w analizach prowadzonych przez Adama Gendźwiłła oraz Tomasza Żółtaka. W ich opinii głównym czynnikiem wpływającym na takie zjawisko była konsolidacja systemu partyjnego na szczeblu ogólnopolskim, która miała miejsce po 2005 roku (Gendźwiłł, Żółtak, 2012, s. 119).

Drugą, bardzo ważną grupą podmiotów na lokalnej scenie politycznej były lokalne ugrupowania polityczne stanowiące zaplecza urzędujących burmistrzów (prezydentów miast). Podmioty te w swym działaniu stawały się coraz bardziej profesjonalne. Następowała przede wszystkim ich instytucjonalizacja. Zasięg ich działalności nie był ograniczony wyłącznie do jednej gminy - bardzo często budowały struktury powiatowe, uczestnicząc w rywalizacji wyborczej do rad powiatów. Nie było już miejsca na inicjatywy lokalne powstające $a d$ hoc, po to, by wziąc udział tylko w wyborach samorządowych. Uczestniczyła w nich coraz mniejsza liczba komitetów wyborczych.

Innym obserwowanym wówczas zjawiskiem było zdobywanie silnej pozycji przez urzędujących burmistrzów (prezydentów miast). Stali się oni rzeczywistymi liderami, wokół których organizowane było życie polityczne w gminie. Występuje jednak pewna dychotomia. Mimo że organizacja życia politycznego jest domeną partii politycznych, to jednak sukces w wyborach odnoszą kandydaci ugrupowań lokalnych, bardzo niechętnie przyznający się do przynależności do jakiejkolwiek partii politycznej czy identyfikujący z jakąkolwiek z nich (choć w przeszłości mieli epizody partyjne). W wyborach w 2006 i 2010 zauważalny był jednak wzrost aktywności struktur partyjnych w rywalizacji o funkcje burmistrzów (prezydentów miast).

Lokalne sceny polityczne charakteryzowały się dużą stabilnością, głównie za sprawą silnej pozycji komitetów wyborczych burmistrzów (prezydentów miast) i eliminowania z lokalnej sceny politycznej ugrupowań powstałych ad hoc. Ciagłość występowała nie tylko w przypadku funkcji burmistrza (prezydenta miasta), ale również jeśli chodzi o organ stanowiący - radę. W znacznej części gmin przedstawiciel tego samego ugrupowania sprawował funkcję przewodniczącego rady przez dwie, a nawet trzy kadencje. Niejednokrotnie były to te same osoby. Poza pojedynczymi przypadkami, w badanych gminach zaobserwowano zjawisko kontynuacji, a nie zmiany. 


\section{Struktura rywalizacji wyborczej w badanych gminach w 2014 roku}

Analiza badań CBOS z 2014 roku wskazywała nasilającą się tendencję do braku akceptacji głosowania w wyborach lokalnych na partie polityczne. O ile w 2010 roku w wyborach na wójta (burmistrza, prezydenta miasta) gotowość do wyboru kandydata popieranego przez jakąś partię polityczną wyrażało około $24 \%$ badanych, o tyle przed ostatnią elekcją było to już tylko $17 \%$. Z kolei odsetek respondentów popierających kandydatów niezwiązanych z żadną partią wzrósł z 48\% w 2010 roku do $67 \%$ w roku 2014. Dość wyraźnie zmniejszył się również odsetek niezdecydowanych (z 28 do 16\%) (CBOS, 124/2014).

$\mathrm{W}$ gminach objętych badaniem w rywalizacji wyborczej wzięło udział 57 komitetów wyborczych, spośród których 22 stanowiły lokalne komitety wyborcze $(38,60 \%)$. Jednak kategoria „lokalny komitet wyborczy” jest zróżnicowana. Należały do niej komitety utworzone: 1) na bazie funkcjonujących już lokalnych stowarzyszeń i organizacji (głównie przez urzędujących burmistrzów); 2) przez osoby kandydujące na funkcje burmistrzów lub prezydentów miast, ale niemające jeszcze zaplecza organizacyjnego oraz 3) przez działaczy partyjnych, którzy nie zdecydowali się na bezpośredni udział w rywalizacji wyborczej własnej partii politycznej, tworząc lokalny komitet wyborczy, stosując de facto kamuflaż polityczny, bądź też tworząc szersze porozumienie z innymi podmiotami. Zaledwie 16 komitetów wyborczych zarejestrowały partie polityczne $(28,07 \%)$. Do komitetów wyborczych należały również tzw. „komitety jednego okręgu" - 19 (33,33\%), utworzone przez pojedyncze osoby, które chciały wziąc udział w rywalizacji wyborczej tylko w jednym okręgu wyborczym. Jednak faktyczną wiedzę o sprawności i aktywności danej kategorii komitetów dają dane dotyczące liczby kandydatów. Blisko 60\% kandydatów brało udział w rywalizacji z list lokalnych komitetów wyborczych, zaś około $38 \%$ to kandydaci partii politycznych. Pozostali to kandydaci jednostkowi.

Z poprzednich elekcji zachowany został podział gmin, w których dominowały lokalne komitety wyborcze (Jarocin, Kępno, Pleszew) oraz komitety wyborcze partii politycznych (Krotoszyn, Ostrów Wielkopolski, Ostrzeszów). W pierwszej kategorii gmin od kilku lat głównymi ugrupowaniami lokalnej polityki są zaplecza urzędujących od wielu lat burmistrzów, w drugiej zaś silne wpływy partii politycznych są zasługą albo Polskiego Stronnictwa Ludowego (Krotoszyn, Ostrzeszów), albo Platformy Obywatelskiej, z których wywodzą się burmistrzowie i prezydent 
miasta. W elekcji 2014 roku powtórzyło się jednak zjawisko kamuflażu politycznego, znane już wcześniej, zwłaszcza w 2002 i 2006 roku, a zanikające $\mathrm{w}$ roku 2010. Z bezpośredniej rywalizacji wyborczej wycofały się tym razem Platforma Obywatelska (Jarocin, Kępno, Ostrzeszów, Pleszew) oraz lewica (Jarocin, Krotoszyn, Ostrów Wielkopolski). Środowiska reprezentujące te opcje polityczne wybrały formułę lokalnego ugrupowania, odstępując od wystawiania komitetów partyjnych. Na etapie zgłaszania list wyborczych aktywnością wykazały się tradycyjnie Polskie Stronnictwo Ludowe, które poza Pleszewem i Ostrowem Wielkopolskim wystawiło własne komitety wyborcze oraz Prawo i Sprawiedliwość (poza Kępnem).

Na 57 komitetów wyborczych możliwość zgłaszania kandydatów na burmistrza (prezydenta miasta) ${ }^{3}$ miało $30(52,63 \%)$, z tego 19 lokalnych oraz 11 partii politycznych. Podobnie jak w 2010 roku w badanych gminach zgłoszono 27 kandydatów na burmistrzów (prezydentów miast). Zmieniła się jednak struktura podmiotów zgłaszających kandydatów. O ile we wcześniejszych elekcjach partie polityczne i lokalne ugrupowania zgłaszały podobną liczbę kandydatów, o tyle podczas elekcji w 2014 roku zdecydowaną większość stanowili kandydaci ugrupowań lokalnych (64\%).

Niektóre partie polityczne, które zastosowały kamuflaż polityczny w wyborach do rady gminy, jako partyjne komitety wyborcze wzięły jednak udział w wyborach do rady powiatu. Analiza materiałów Państwowej Komisji Wyborczej wskazuje, że rozwiązanie takie przyjęła Platforma Obywatelska w Pleszewie (bez mandatu) i Jarocinie (1 mandat); SLD Lewica Razem w Jarocinie (1 mandat) i Ostrowie Wielkopolskim (2 mandaty) oraz Polskie Stronnictwo Ludowe w Pleszewie (9 mandatów) i Ostrowie Wielkopolskim (8 mandatów).

\section{Wyniki rywalizacji wyborczej do rad gmin oraz burmistrzów (prezydenta miasta)}

Frekwencja wyborcza w badanych gminach wyniosła 47,39\% i była o niecałe 2 pp niższa od frekwencji z 2010 roku. Była jednak „gminnie” zróżnicowana: od ponad 54\% w Kępnie, gdzie tradycyjnie frekwencja

${ }^{3}$ Możliwość zgłaszania kandydatów na burmistrzów (prezydentów miast) mają komitety wyborcze, które zarejestrowały listy wyborcze do rady gminy w co najmniej połowie okręgów wyborczych. 
należy do jednych z najwyższych na badanym terenie, do 42,78\% w sąsiednim Ostrzeszowie (tam z kolei frekwencja od lat jest najniższa). W opinii autora tym, co może determinować udział mieszkańców w wyborach, jest stawka wyborcza. Wzrost frekwencji odnotowano w gminach, w których nastąpiła silna polaryzacja w wyborach burmistrzów i prezydentów miast (Jarocin, Ostrów Wielkopolski). Sytuacja odwrotna obniżała frekwencję, czego najlepszym przykładem był Pleszew. Podczas ostatnich wyborów zgłoszony został wyłącznie jeden kandydat (urzędujący od 1997 roku burmistrz), w związku z czym frekwencja spadła o ponad 5,7 pp.

Wynik wyborczy w wyborach do rad gmin odzwierciedla aktywność komitetów wyborczych w zgłaszaniu list wyborczych. Na 128 mandatów we wszystkich gminach 80 zdobyły lokalne komitety wyborcze $(62,50 \%)$. Zaledwie 4 mandaty przypadły kandydatom, którzy zarejestrowali własne komitety wyborcze, a ich aktywność skoncentrowała się tylko w jednym okręgu wyborczym. Partie polityczne zdobyły 48 mandatów (37,50\%), z tego aż 15 mandatów uzyskała sama Platforma Obywatelska w Ostrowie Wielkopolskim (w jedynej gminie miejskiej, która została poddana badaniu).

Tabela 1

Mandaty lokalnych komitetów wyborczych oraz partyjnych komitetów wyborczych w radach miast w latach 2002-2014 (\%)

\begin{tabular}{||l|r|r|r|r|r|r|r|r||}
\hline \multirow{3}{*}{ Gmina } & \multicolumn{4}{|c|}{ Lokalne komitety wyborcze } & \multicolumn{4}{c|}{ Partyjne komitety wyborcze } \\
\cline { 2 - 9 } & \multicolumn{4}{|c|}{ rok wyborów } & \multicolumn{4}{c|}{ rok wyborów } \\
\cline { 2 - 9 } & $\mathbf{2 0 0 2}$ & $\mathbf{2 0 0 6}$ & $\mathbf{2 0 1 0}$ & $\mathbf{2 0 1 4}$ & $\mathbf{2 0 0 2}$ & $\mathbf{2 0 0 6}$ & $\mathbf{2 0 1 0}$ & $\mathbf{2 0 1 4}$ \\
\hline Jarocin & 61,90 & 95,24 & 66,67 & 80,95 & 38,10 & 4,76 & 33,33 & 19,05 \\
\hline Kępno & 76,19 & 90,48 & 76,19 & 76,19 & 23,81 & 9,52 & 23,81 & 23,81 \\
\hline Krotoszyn & 52,38 & 66,67 & 42,86 & 61,90 & 47,62 & 33,33 & 57,14 & 38,10 \\
\hline Ostrów Wlkp. (m.) & 47,83 & 17,39 & 43,48 & 34,78 & 52,17 & 82,61 & 56,52 & 65,22 \\
\hline Ostrzeszów & 38,10 & 23,81 & 9,52 & 33,33 & 61,90 & 76,19 & 90,48 & 66,67 \\
\hline Pleszew & 47,62 & 61,90 & 66,67 & 90,48 & 52,38 & 38,10 & 33,33 & 9,52 \\
\hline Razem & 53,91 & 58,59 & 50,78 & 62,50 & 46,09 & 41,41 & 49,22 & 37,50 \\
\hline
\end{tabular}

Źródło: Obliczenia własne na podstawie danych Państwowej Komisji Wyborczej.

Tylko w Ostrowie Wielkopolskim (Platforma Obywatelska) oraz w Ostrzeszowie (Polskie Stronnictwo Ludowe wraz z Lewica) sukces odniosły partie polityczne. W gminach tych partie polityczne mają nieco powyżej $65 \%$ mandatów w radach miast. Jednak wyborczy sukces partii politycznych nie był tak spektakularny jak lokalnych ugrupowań 
politycznych w pozostałych gminach. W Jarocinie i Pleszewie lokalne ugrupowania mają w radzie ponad 80\% mandatów, zaś w Kępnie ponad $70 \%$. Nawet w Krotoszynie, w którym silną pozycję tradycyjnie zajmuje PSL, sukces odniosły lokalne ugrupowania (ponad 60\% miejsc w radzie). Na uwagę zasługują uzyskane przez nie wyniki. Z 76 mandatów aż 35 mandatów zdobyły komitety wyborcze burmistrzów z Jarocina (15), Pleszewa (13) oraz Kępna (7). W gminach tych rady miejskie liczą po 21 radnych.

Wyniki osiagane przez lokalne ugrupowania świadczą również o tym, że kolejność kandydatów na kartach wyborczych nie miała znaczenia. W przeciwnym razie sukces osiagaliby kandydaci komitetów wyborczych partii politycznych. Podobne zjawisko braku związku między sukcesem wyborczym a miejscem na liście wyborczej autor zauważył nawet, kiedy obowiązywała jeszcze ordynacja proporcjonalna. Badając wybory z 2006 roku, zauważono, że kandydaci czterech lokalnych komitetów wyborczych (Wszystko dla Kalisza, Samorządowej Inicjatywy Obywatelskiej i Samorządowego Porozumienia Ludowego z Krotoszyna oraz Ziemi Jarocińskiej) byli umieszczeni na listach wyborczych w porządku alfabetycznym, zaś radnymi zostawały osoby z dalszych miejsc (Ptak, 2011, s. 123).

Zmiany nastapiły również w samych radach gmin. Wskaźnik reelekcji radnych zmniejszył się o ponad 10 pp. i był zbliżony do wyniku z 2006 roku.

Tabela 2

Wskaźnik reelekcji radnych rad gmin (dane w \%)

\begin{tabular}{|l|c|c|c||}
\hline \multicolumn{1}{|c|}{ Gmina } & $\mathbf{2 0 0 6}$ & $\mathbf{2 0 1 0}$ & $\mathbf{2 0 1 4}$ \\
\hline Jarocin & 42,86 & 52,38 & 52,38 \\
\hline Kępno & 45,00 & 57,14 & 42,86 \\
\hline Krotoszyn & 23,81 & 66,67 & 61,90 \\
\hline Ostrów Wlkp. (m.) & 39,13 & 52,17 & 52,17 \\
\hline Ostrzeszów & 57,14 & 71,43 & 33,33 \\
\hline Pleszew & 66,67 & 57,14 & 47,62 \\
\hline Ogółem & 45,77 & 59,49 & 47,38 \\
\hline
\end{tabular}

Źródło: Obliczenia własne na podstawie danych Państwowej Komisji Wyborczej.

Największe zmiany dokonały się w Ostrzeszowie. Zaledwie co trzeci radny miał doświadczenie z poprzedniej kadencji. Wybory przegrywali 
(bądź nie brali udziału w rywalizacji) głównie posiadający doświadczenie samorządowe radni z PSL oraz SLD.

Ciekawie przedstawiają się wyniki elekcji burmistrzów i prezydentów miast. Generalnie można uznać, że wystąpiło zjawisko kontynuacji (poza Ostrowem Wielkopolskim), jednak w każdym z miast miała ona inny charakter. W Pleszewie i Ostrzeszowie wygrali urzędujący burmistrzowie. W pierwszym z miast burmistrz nie miał żadnego kontrkandydata, zaś w drugim zwyciężył kandydat reprezentujący PSL w pierwszej turze $(63,54 \%)$, pokonując trzech konkurentów. W Krotoszynie z rywalizacji wycofał się sprawujący już kilka kadencji burmistrz z PSL, ale jego miejsce zajął jego zastępca, również reprezentujący ludowców $(49,29 \%$ w pierwszej turze). W Jarocinie i Kępnie wygrali burmistrzowie, którzy powrócili na swój urząd po czteroletniej przerwie. W Jarocinie przerwa spowodowana była dość kontrowersyjnym wyrokiem sądowym, na podstawie którego burmistrz został prawomocnie skazany na początku poprzedniej kadencji. W Kępnie w 2010 roku burmistrz przegrał wybory. Przykłady Jarocina i Kępna są o tyle ciekawe, że pomimo przerwy w sprawowaniu swojej funkcji i bycia formalnie poza lokalną polityka, burmistrzowie ci zdołali utrzymać przez ten czas własne zaplecza polityczne. W Jarocinie dawny burmistrz zwyciężył w pierwszej turze $(53,56 \%)$, pokonując tego urzędującego przez ostatnie cztery lata (w przeszłości tworzyli wspólną inicjatywę polityczną). Z kolei w Kępnie starający się o reelekcję po czteroletniej przerwie burmistrz bliski był zwycięstwa w pierwszej turze głosowania (48,63\%). Zarówno w Jarocinie, jak i w Kępnie urzędujący przez ostatnie cztery lata burmistrzowie nie tylko przegrali wybory, ale również nie potrafili stworzyć własnego zaplecza politycznego, skutecznie biorącego udział w rywalizacji wyborczej w 2014 roku. Jedynie w Ostrowie Wielkopolskim urzędujący przez ostatnie cztery lata prezydent miasta przegrał w drugiej turze głosowania (po roku został Posłem na Sejm RP). Struktura rywalizacji wyborczej w Ostrowie Wielkopolskim była dość specyficzna. Kandydowało aż sześć osób, w tym, oprócz urzędującego prezydenta, również jego zastępca oraz były koalicjant. W drugiej turze powstała „antyprezydencka” koalicja. Dodatkowo w trakcie kadencji nastąpiła dekompozycja klubu radnych Platformy Obywatelskiej. Trzech członków zostało z niego wykluczonych, zaś dwóch opuściło go z własnej woli. Większosśc w radzie zaczęła budować nowo wybrana prezydent miasta kandydująca z lokalnego komitetu wyborczego (wcześniej reprezentowała lewicę). 


\section{Podsumowanie}

Prowadzone badania ukazały pogłębiający się proces wycofywania się z bezpośredniej rywalizacji wyborczej przez patie polityczne. Wzrost aktywności partii w lokalnych elekcjach z 2010 roku nie został zachowany w 2014 roku. O słabości partii politycznych w lokalnej polityce decyduje przede wszystkim: 1) negatywna ocena partii politycznych przez znaczną część polskiego społeczeństwa; 2) silna polaryzacja polskiej sceny politycznej (Platforma Obywatelska versus Prawo i Sprawiedliwość); 3) słabość struktur partyjnych (poza PSL) oraz 4) brak lokalnych liderów w szeregach partii politycznych. Sprawia to, że na poziomie lokalnym w rywalizacji wyborczej z dużym sukcesem uczestniczą lokalne ugrupowania polityczne.

Przykłady badanych gmin świadczą o tym, że wielu lokalnych działaczy samorządowych posiadło doskonałe umiejętności ,,politycznej adaptacji” do zmieniających się nastrojów społecznych. Spadek poparcia dla partii politycznej powoduje rezygnację z partyjnego szyldu podczas wyborów samorządowych na rzecz lokalnego ugrupowania. W elekcji w 2014 roku zauważalne było to zwłaszcza w przypadku Platformy Obywatelskiej. I choć według badań CBOS-u bezpośrednio przed wyborami samorządowymi poparcie dla tej partii, jak i dla rządu, było bardzo wysokie, to jednak lokalni działacze zauważyli pierwsze symptomy spadku poparcia i złego klimatu wokół partii. Istotne znacznie ma fakt, że badane gminy to jednostki miejsko-wiejskie, gdzie pewne zjawiska „odwrotu” od poparcia dla partii są lepiej i szybciej zauważalne niż na poziomie dużych miast. I choć lokalni działacze nie prowadzą badań preferencji partyjnych w swojej gminie, to jednak mogą dokonywać stosownej oceny dzięki częstym kontaktom z mieszkańcami, a bezpośrednio przed wyborami weryfikować to przy konstruowaniu list wyborczych (np. odmowa kandydowania $\mathrm{z}$ list partyjnego komitetu wyborczego). Kryzys dostrzegalny był również w przypadku lewicy, która w wyborach wzięła udział jako Koalicyjny Komitet Wyborczy SLD Lewica Razem. Najczęściej lokalni liderzy partii brali udział w rywalizacji wyborczej w formule lokalnego komitetu wyborczego. Nie oznacza to, że partie polityczne, zwłaszcza rządzące w sejmikach wojewódzkich Platforma Obywatelska oraz Polskie Stronnictwo Ludowe, utraciły wpływy na szczeblu lokalnym. Dystrybucja środków z UE na poziomie regionalnym sprawia, że relacje między przedstawicielami tych szczebli władzy mogą rodzić nawet zjawisko klientelizmu i budowy relacji patron-klient. 
Inaczej sytuacja przedstawiała się w przypadku Prawa i Sprawiedliwości. Zauważalne było zjawisko wzrostu poparcia dla partii w skali kraju, stąd też aktywność i zdyscyplinowanie partyjnych struktur na etapie zgłaszania list wyborczych było bardzo widoczne. Jednak w rywalizacji PiS poniosła dotkliwą porażkę (w 2010 roku z list PiS-u wybrano 8 radnych, zaś w 2014 tylko 1). W swoich szeregach partia nie posiadała (jeszcze?) lokalnych liderów (sołtysów, strażaków z OSP, działaczy sportowych, członkiń kół gospodyń wiejskich), którzy najczęściej zasilali ugrupowania polityczne burmistrzów lub Polskiego Stronnictwa Ludowego (Ptak, 2016, s. 195). I choć podczas elekcji samorządowej z 2014 roku PSL zachowało silne wpływy w środowisku wiejskim, to jednak pojawiły się pierwsze symptomy spadku poparcia. Dla partii tej niepokojącym zjawiskiem może być to, że zmniejszenie liczby radnych wystapiło w gminach, w których burmistrzowie są członkami Polskiego Stronnictwa Ludowego. Oceny tego zjawiska nie zmienia sukces ludowców w wyborach do sejmików województw, gdzie o wynikach wyborów zadecydowała przede wszystkim konstrukcja karty do głosowania, a nie realne poparcie społeczne. Tendencja spadku poparcia dla ludowców na wsi została w pełni potwierdzona w późniejszych wyborach do Sejmu RP w 2015 roku. Na terenach wiejskich nastapił wzrost poparcia dla PiS (z 35,8\% w 2011 roku do $45,5 \%$.) Z kolei poparcie dla PSL spadło z 16,8\% do 9,7\%. W opinii Jerzego Bartkowskiego, wyniki uzyskane podczas wyborów parlamentarnych w 2015 roku przez PiS oraz PSL, wraz z innymi zjawiskami, także symbolicznymi (m.in. porażki wyborcze długoletnich liderów ludowców w wyborach), doprowadziły do sytuacji, w której to właśnie PiS stał się główną formacją polityczną na obszarach wiejskich (Bartkowski, 2016, s. 226-227).

Wybory samorządowe w badanych gminach miejsko-wiejskich wykazały, że zarówno Platforma Obywatelska, jak i Prawo i Sprawiedliwość, choć posiadają struktury partyjne, nie mają lokalnych liderów, którzy po wprowadzeniu formuły większościowej w wyborach do rady gminy mogliby wygrać rywalizację wyborczą. Podobnie jest w rywalizacji o funkcje burmistrzów i prezydentów miast. Dopiero szyld partyjny, mało istotny, a nawet przeszkadzający w wyborach lokalnych, jest już znaczący na poziomie regionalnym, który umożliwia sprawowanie władzy przez partie polityczne w samorządzie wojewódzkim. Występuje więc zjawisko „partyjnej próżni”. Na poziomie lokalnym, zwłaszcza w małych miastach oraz na obszarach wiejskich, struktury rozbudowane i stosunkowo trwałe posiada nadal Polskie Stronnictwo Ludowe. PiS, chcąc utrzymać domi- 
nującą pozycję na polskiej wsi, którą zdobył po ostatnich wyborach parlamentarnych, musi przystapić do budowy struktur. Osiagnnięciu tego celu sprzyjają zapewne rozległe zmiany kadrowe w rządowej administracji na poziomie lokalnym (np. oddziały powiatowe Agencji Restrukturyzacji i Modernizacji Rolnictwa, Kasy Rolniczego Ubezpieczenia Społecznego itp.).

Innym badanym czynnikiem determinującym rywalizację wyborczą była zmiana ordynacji wyborczej. Przyjęto hipotezę, że rozszerzenie ordynacji większościowej, po pierwsze, wzmocniło najsilniejsze ugrupowania lokalnej polityki, a po wtóre, nie zaktywizowało mieszkańców do rejestrowania własnych, wcześniej nieobecnych, komitetów wyborczych. W znacznej części gmin zmiana ordynacji rzeczywiście wzmocniła najsilniejsze ugrupowania w radzie. Były to najczęściej zaplecza polityczne burmistrzów. Zjawisko to nie wystąpiło jedynie w dwóch gminach, w których najsilniejsze było PSL (partia w radzie utraciła po jednym mandacie). Jeżeli jednak do osiagniętych wyników wyborów z 2014 roku zastosować indeks agregacji L. Mayera, wyrażający stosunek procentu mandatów kontrolowanych przez najsilniejsze ugrupowanie do ogólnej liczby podmiotów reprezentowanych w radzie (Antoszewski, 2004, s. 193), okazuje się, że lokalne sceny polityczne stały się bardziej stabilne i spójne. Analizując cztery ostatnie elekcje samorządowe $(2002,2006,2010,2014)$, można wskazać, że praktycznie we wszystkich badanych gminach indeks agregacji był najwyższy po ostatniej elekcji. Formuła większościowa sprzyja więc stabilności i spójności lokalnych scen politycznych. Można więc zakładać, że kolejne elekcje samorządowe (jeżeli oczywiście zostaną zachowane jednomandatowe okręgi wyborcze) będą sprzyjać kształtowaniu się w gminach systemu politycznego zdominowanego przez najsilniejsze ugrupowania. W konsekwencji założenia teorii Duvergera mogą być urzeczywistnione także w polskich gminach.

Przyjęta formuła wyborcza doprowadziła również do dysproporcjonalności na co już zwracał uwagę M. Duverger. W radzie gminy zabrakło reprezentacji komitetów wyborczych, które w skali gminy zdobyły nawet po kilkanaście procent głosów. W takiej sytuacji znalazł się głównie PiS, który zdobywając w trzech gminach od blisko 10 do 14\% głosów w skali gminy, nie ma żadnego przedstawiciela w radzie. W podobnej sytuacji znalazły się ugrupowania lokalne w dwóch kolejnych gminach. W 2010 roku, kiedy obowiązywała ordynacja proporcjonalna, dysproporcje takie w zasadzie nie miały miejsca. 
Formuła większościowa wcale nie zaktywizowała osób, które wcześniej bezpośrednio nie angażowały się w lokalną politykę. Przeciwnicy ordynacji proporcjonalnej bardzo często wskazywali, że listy wyborcze zawierające kilka (lub nawet kilkanaście) nazwisk z jednego ugrupowania prowadziły do „blokowania” pierwszych miejsc (tzw. „biorących”) przez wąskie grono politycznych działaczy. Formuła większościowa nie skłoniła jednak kandydatów indywidualnych do udziału w rywalizacji pomimo znacznego ułatwienia w rejestrowaniu własnego komitetu wyborczego. Wśród wszystkich kandydatów biorących udział w rywalizacji podmioty indywidualne stanowiły zaledwie 2\%. Także wśród samych radnych odsetek osób wywodzących się z własnego komitetu wyborczego jest niewielki $(3,13 \%)$.

Innym mankamentem zastosowanej formuły wyborczej jest zaobserwowane zjawisko koncentrowania się radnych na własnym okręgu wyborczym, co uwidacznia się m.in. w składanych przez radnych interpelacjach. Dotyczą one przede wszystkim spraw własnego okręgu wyborczego (a nie całej gminy). Przedkłada się to na konstrukcję budżetu gminy. Zadania ważne z punktu widzenia całej gminy tracą na znaczeniu z uwagi na koncentrowanie się na sprawach poszczególnych okręgów wyborczych.

Na podstawie badań można stwierdzić, że czynnikiem w najwyższym stopniu wpływającym na charakter i kształt lokalnego systemu władzy jest osoba burmistrza (prezydenta miasta). Jego wybór politycznej kariery (lokalne ugrupowanie versus partia polityczna) wpływa de facto na wynik wyborów, a w konsekwencji na kształt lokalnej sceny politycznej. O sile podmiotów lokalnej polityki decyduje przede wszystkim przynależność burmistrza (prezydenta miasta). Dla współczesnej lokalnej sceny politycznej kluczowe znacznie miała elekcja z 2002 roku, kiedy po raz pierwszy wybierano wójtów i burmistrzów (prezydentów miast) w bezpośrednich wyborach. To wówczas w wielu przypadkach rozpoczęła się budowa własnych struktur przez burmistrzów. Nawet jeśli byli wówczas kandydatami partii politycznych (SLD-UP) bądź lokalnych ugrupowań o orientacji centroprawicowej (w wielu miastach realizowana była wówczas idea PO-PiS-u), w okresie późniejszym rezygnowali z partyjnej przynależności bądź z bezpośredniego identyfikowania się z daną formacją polityczną. Zjawiska tego nie zaobserwowano wśród wójtów i burmistrzów z PSL. Partia ta w gminach wiejskich i w małych miastach przez cały czas zachowała swoją silną pozycję. Polityczna siła burmistrzów i prezydentów miast była na tyle znacząca, że w wielu gminach, nawet 
gdy oni sami kończyli działalność w samorządzie, ich miejsca zajmowały osoby z zaplecza politycznego (bardzo często byli to ich zastępcy). Podobne zjawiska występowały również w badanych gminach.

W kontekście wyborczej porażki Prawa i Sprawiedliwości rodzi się pytanie, czy mająca samodzielną większość w parlamencie partia zdecyduje się na zmiany, które w przyszłości moga jej dać większe wpływy w lokalnej polityce. Dotyczy to głównie zmian w prawie wyborczym w zakresie: 1) formuły wyborczej (powrót do formuły proporcjonalnej); 2) długości sprawowania funkcji burmistrza (ograniczenie czasu sprawowania funkcji do dwóch kadencji); 3) wprowadzenia zakazu łączenia funkcji radnego rady gminy $\mathrm{z}$ innymi funkcjami w dziedzinie lokalnej polityki (np. funkcją sołtysa, przewodniczącego zarządu osiedla).

\section{Bibliografia}

Alberski R., Antoszewski A., Lisicka H., Skrzypiński D., Solarz R. (2001), Wybory do rad gmin na Dolnym Ślasku (1990-1998), Wydawnictwo Prawo Ochrony Środowiska, Wrocław.

Antoszewski A. (2004), Wzorce rywalizacji politycznej we wspótczesnych demokracjach europejskich, Wydawnictwo Uniwersytetu Wrocławskiego, Wrocław.

Bartkowski J. (2016), Mapa polityczna polskiej wsi, w: Polska wieś 2016. Raport o stanie wsi, red. J. Wilkin, I. Nurzyńska, Wydawnictwo Naukowe SCHOLAR, Warszawa.

Duverger M. (19540), Les partis politiques, Libraire Armand Colin, Paris.

Gendźwiłł A., Żółtak T. (2012), Bezpartyjność w powolnym odwrocie. Analiza rozpowszechnienia bezpartyjności w wyborach lokalnych w Polsce 2002-2010, „Studia Regionalne i Lokalne”, nr 1.

Gendźwiłł A., Cześnik M., Flis J., Haman J., Materska-Sosnowska A., Michalak B., Pietrzyk P., Zbieranek J. (2016), Nieważne głosy, ważny problem. Wyniki badania kart do glosowania z wyborów do sejmików województw 2014, Fundacja im. Stefana Batorego, Warszawa.

Haman J. (2003), Demokracja, Decyzje, Wybory, Wydawnictwo Naukowe Scholar, Warszawa.

Kamiński M. M. (2016), Okręgi jednomandatowe, Centrum im. Adama Smitha.

Kurczewski J. (2008), Antypolityka jako polityka bez partii, w: Oblicza lokalności. Ku nowym formom Życia lokalnego, red. J. Kurczewska, Wydawnictwo IFiS PAN, Warszawa.

Kurczewski J. (2007), Lokalne wzory kultury politycznej. Podsumowanie, w: Lokalne wzory kultury politycznej. Szkice ogólne i opracowania monograficzne, red. J. Kurczewski, Wydawnictwo TRIO, Warszawa. 
Polska polityka po nominacji Donalda Tuska na szefa Rady Europejskiej (2014), CBOS, nr 127, Warszawa.

Preferencje partyjne po wyborze Donalda Tuska na Przewodniczacego Rady Europejskiej (2014), CBOS, nr 126, Warszawa.

Ptak A. (2010), Ewolucja systemu wyborczego do organów samorzadu terytorialnego w Polsce, w: Prawo wyborcze $i$ wybory. Doświadczenia dwudziestu lat procesów demokratyzacyjnych w Polsce, red. A. Stelmach, Wydawnictwo Naukowe WNPiD UAM, Poznań.

Ptak A. (2010), Podmioty lokalnej rywalizacji wyborczej, w: Doświadczenia i perspektywy rozwoju samorzadu terytorialnego $i$ zawodowego, red. A. Antkowiak, Wydawnictwo Adam Marszałek, Toruń.

Ptak A. (2011), Rywalizacja polityczna w samorzadach lokalnych. Studium wybranych gmin. Poznań-Kalisz.

Ptak A. (2016), Sołectwa w lokalnym systemie władzy, Wydawnictwo Naukowe Scholar, Warszawa.

Stosunek do rzqdu w listopadzie (2014), CBOS, nr 156, Warszawa.

Swianiewicz P. (2016), Wspótczesne badania nad samorzqdem i polityka lokalna, w: Polska gmina 2015, red. G. Gorzelak, Wydawnictwo Naukowe SCHOLAR, Warszawa.

Ustawa z dnia 5 stycznia 2011 roku Kodeks wyborczy, Dz. U. 2011, Nr 21, poz. 112 ze zmianami.

Wybory samorzqdowe (2014), CBOS, nr 124, Warszawa.

Zaufanie do polityków u progu nowego sezonu politycznego (2014), CBOS, nr 120, Warszawa.

\section{The determinants of electoral competition in local government elections}

\section{Summary}

The paper attempts to present and explain the determinants of electoral competition and results, thereby influencing local political landscapes after the 2014 local government elections. The primary determinants analyzed in the paper include: (1) changes introduced to local government electoral law; (2) the socio-political situation in Poland before the local government elections; and (3) the character of local political arenas. A study has been carried out which demonstrated that political parties have withdrawn from direct electoral competition at the local level. The municipalities examined evidence that numerous local government activists have perfected the skill of "political adaptation to evolving social sentiments. The changes introduced to the electoral law, in particular the implementation of the majority formula in the elections to municipal councils, have resulted in the following, among other things: (1) mayors and their direct political backgrounds have been additionally empowered 
in the local system; (2) election results have become disproportionate; (3) individuals lacking institutional political support have been scarcely interested in taking part in the electoral competition; and (4) councilors have focused on the matters of their own respective constituencies in their work. The most influential factor in local government elections and, thereby decisive in shaping the local system of power is the mayor (president of the town).

Key words: local government elections, municipality, electoral formula, single-member constituency, mayor 